\title{
A longer service life of intermediate elastic fastenings KPP-5 due to application of pads PRP-3.2
}

\author{
Oleksandr Darenskiy ${ }^{1, *}$, Nataliya Bygaets ${ }^{1}$, Olga Horiyinova ${ }^{1}$, Sergey Voznenko ${ }^{1}$, and \\ Stanislav Kulik ${ }^{2}$ \\ ${ }^{1}$ Track and Track Facility Department, Ukrainian State University of Railway Transport, Feuerbach \\ Sq. 7, 61050, Kharkiv, Ukraine \\ ${ }^{2}$ The Kupiansk-Uzlovaya track maintenance department, Zheleznodorozhnaya Sq. 10, 63709 \\ Kupiansk, Ukraine
}

\begin{abstract}
Since 2003 Ukrainian railways have used KPP-5 intermediate elastic fastenings. These fastenings unlike their predecessors (for example, terminal-bolted fastenings (KB) widely used on railways), first of all, have fewer elements. The KPP-5 fastening does not include screw joints, which considerably increases the pressing force between rail and tie, and resistance to track displacement forces. This may lead to reduction of the total labour input for routine track maintenance due to cutback of track works needed for mounting terminal and insert bolts. The article deals with forecasting the operational life of PRP 3.2 (9mm depth) and PRP 3.2.1 pads $(10 \mathrm{~mm}$ depth). In engineering the operational life is a time interval (for the railway track - tonnage passed) during which the element fulfils its functions. One of the main reasons why the assembly unit KPP-5 fails is low pressing forces between rail and tie. It occurs due to many processes; among the basic ones is the changed characteristic of underrail pads. And the application of new types of pads - PRP $3.2(9 \mathrm{~mm})$ and PRP 3.2.1. $(10 \mathrm{~mm})$ may solve this problem.
\end{abstract}

\section{Introduction}

The KPP-5 intermediate elastic fastenings have been applied on Ukrainian railways since 2003. The normative documents [1-6] stipulate laying down continuous welded rails on sections of various tonnages along straight lines and curves of the radii $350 \mathrm{~m}$ and more. The length of continuous welded rails can be equal to the length of a block section or a railway haul (over length rails).

For continuous welded rails one of the main problems for intermediate fastenings is to create sufficient per-unit length resistance, i.e to provide the pressing force between rail and tie more than $23 \mathrm{kN}$. In operation resilient terminals and pads of the track suffer from residual deformations, liners wear out, the physical and mechanical characteristics of pads change, and all these factors lead to lower pressing forces. Application of pads PRP 3.2 and

* Corresponding author: ppx_xiit@kart.edu.ua 
PRP 3.2.1 can prolong the operational life of the assembly unit, however, it is necessary to know dependencies of changes in the indicated parameters and, thus, to determine time when pads should be replaces and the operational life of the assembly as a whole [7-11].

\section{The basic part}

The mounting of the assembly unit KPP-5 provokes initial vertical deformation of the spring terminal. And each terminal presses a rail base to a tie with the force $Q_{\text {term }}^{\text {init }}$ which can be defined as

$$
Q_{\text {term }}^{\text {init }}=r_{\text {term }} \cdot \Delta Z_{\text {init }}
$$

where $r_{\text {term }}$ is the rigidity of the spring terminal at vertical deformations.

Under the terminal pressure $2 \cdot Q_{\text {term }}^{\text {init }}$ the underrail pad shrinks and creates the elastic (spring) resistance $Q_{\text {pad }}$. The shrinkage of the pad causes the inverse resilient deformation of the terminals leading to a decrease in the terminal pressing forces. Equilibrium of forces in the assembly unit occurs when the mounting forces of terminal pressure equal the elastic resistance of the pad

$$
Q_{\text {mount }}=u_{\text {pad }}^{\text {stat }} \cdot \Delta Z_{\text {pad }}^{\text {mount }}
$$

where $u_{p a d}^{\text {stat }}$ is the rigidity of a pad at static pressing;

$\Delta Z_{\text {pad }}^{\text {mount }}$ is the mounting pressing of the pad in an assembly.

As the structural peculiarity of the fastening KPP-5 is the equilibrium of the deformations of the pad and the inverse deformation of the terminal, the mounting pressing of the terminal can be presented as

$$
Q_{\text {mount }}=Q_{\text {init }}^{\text {mount }}-\Delta Q=\mathcal{K}_{\text {pad }}\left(\Delta Z_{\text {init }}-\Delta Z_{\text {pad }}^{\text {mount }}\right)
$$

Or, considering expression (2), the mounting pressing on the pad can be defined as

$$
Q_{\text {mount }}=\frac{2 \cdot \mathcal{K}_{p a d} \cdot Z_{\text {init }}}{u_{\text {pad }}^{\text {stat }}+2 \cdot r_{\text {pad }}}
$$

Thus, the mounting pressing on the terminal when laying down into the track equals to

$$
Q_{\text {mount }}=r_{\text {pad }}\left(\Delta Z_{\text {init }}-\Delta Z_{\text {pad }}^{\text {mount }}\right)
$$

On the basis of the analysis of the dimensions of structural elements of the KPP-5 fastenings (Fig. 1-3), the initial deformation of the elastic terminals depends on the thickness of the rail pad and is in a range of $11.24-13.24 \mathrm{~mm}$. 


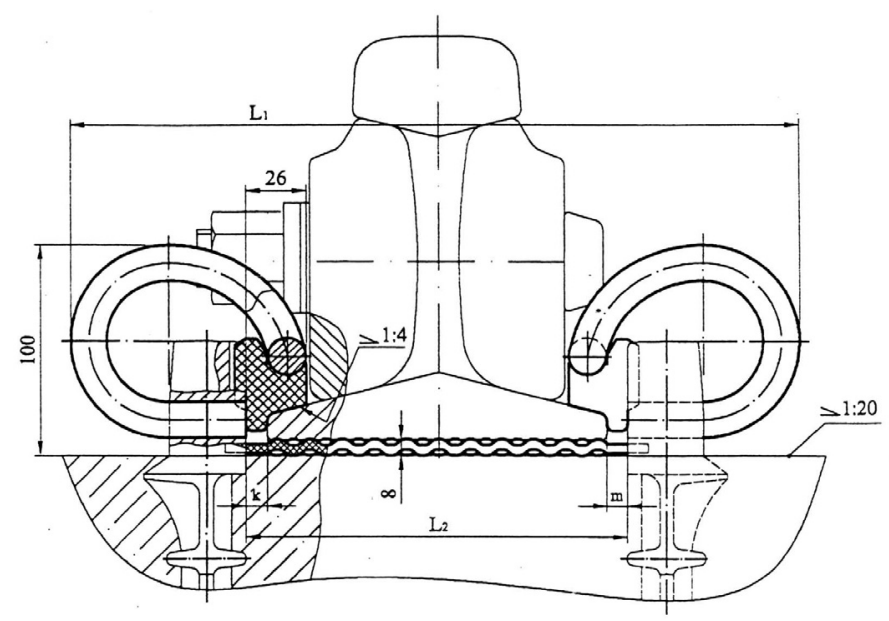

Fig. 1. Basic dimensions of the KPP-5 assembly unit

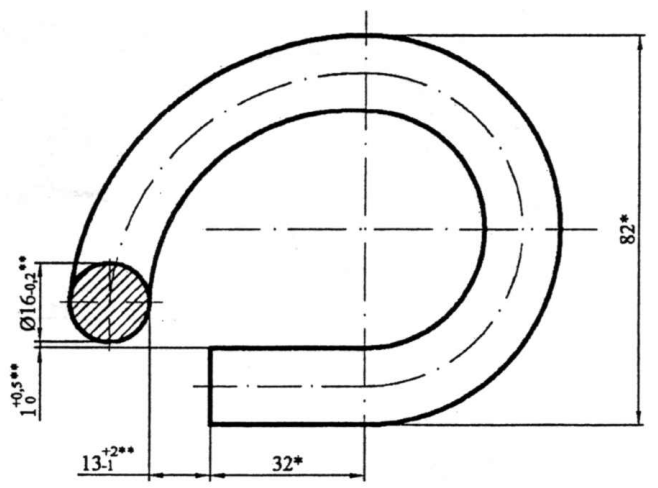

Fig. 2. Basic dimensions of the KP 5.2 terminal

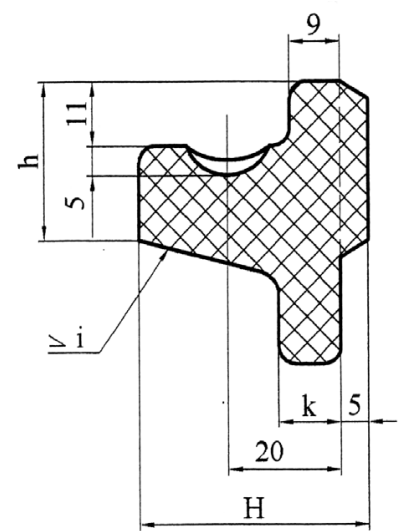

Fig. 2. Basic dimensions of the insulating liner VIP-65.11

The rigidity of the terminals, determined in the laboratory environment, is $1.4 \mathrm{kN} / \mathrm{mm}$.

In track operation the mounting pressing of the terminals to the ties will be reduced due to residual deformations and deterioration of the underrail pad, final deformations of the terminals and deterioration of holes in the anchors and deterioration of the concrete of the 
underrail base, which increase the distance between the anchor's axle and the underrail base of the tie

$$
Q_{\text {mount }}=r_{\text {pad }}\left(\Delta Z_{\text {init }}-\Delta Z_{\text {pad }}^{\text {mount }}-\Delta h_{\text {pad }}-\delta_{h}-\Delta h_{\text {anch }}\right)
$$

where $\Delta h_{p a d}$ is the final deformation of the pad; $\delta_{h}$ is the final deformations of the terminal; $\Delta h_{\text {anch }}$ is an increase of the distance between the underrail base and the anchor's top.

It should be mentioned that apart from the residual deformations and deterioration, in operation the assembly unit suffers from changes in rigidity (both dynamic and static) in the underrail pads.

The empirical dependency of increased static rigidity of the pad is

$$
u_{p a d}^{\text {stat }}=u_{p a d}+0.27 \cdot 10 \cdot t
$$

Since the changes in some parameters depend not only on the service cycle, but also on the conditions of their power work, which can be generalized by the factor of the tonnage transported along the sections, the calculations were conducted for four load capacity values: $15,3045,60 \mathrm{~m}$ tkm gross $/ \mathrm{km}$ per year.

Fig. 4, 5 present generalized diagrams of changes in the pressing force between rail and tie in the assembly unit. The analysis of the diagrams showed that the pressing force was decreasing to a critical value of $20 \mathrm{kN}$. The reference periods for the pressing force in the assembly unit to be restored are given in Table 1.

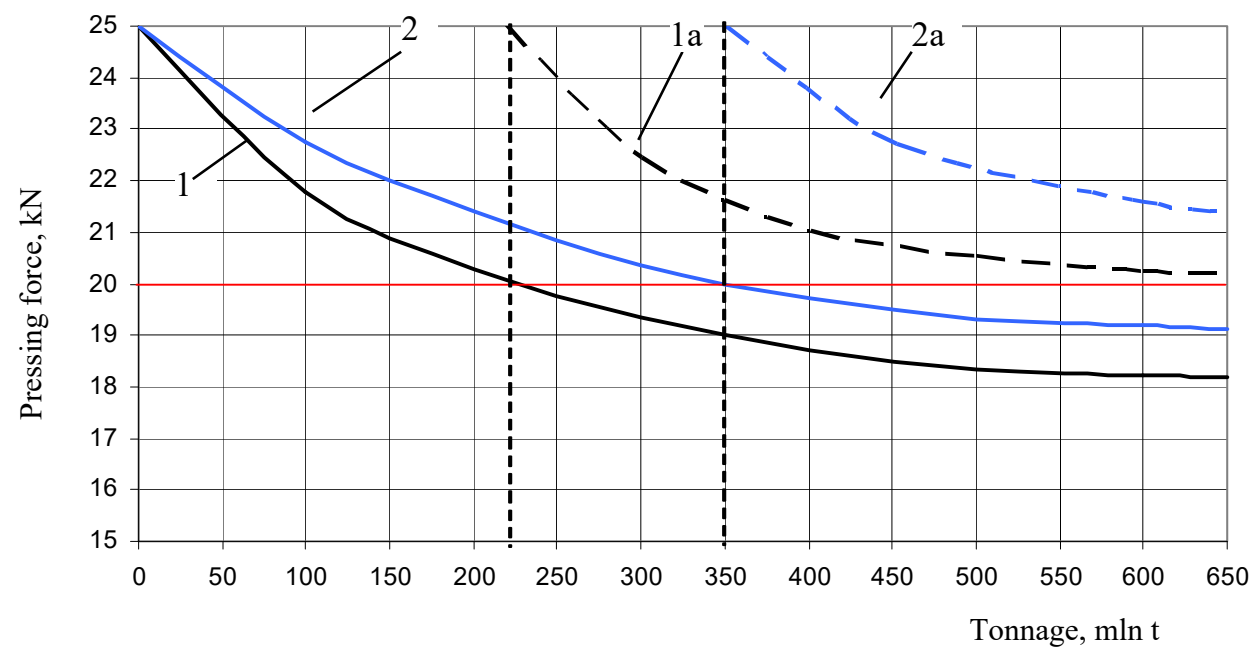

Fig. 4. Diagram of change in the pressing force between rail and tie in the assembly unit KPP-5: 1 - traffic density $15 \mathrm{mln}$ tkm gross $/ \mathrm{km}$ per year; 2 - traffic density $30 \mathrm{mln}$ tkm gross $/ \mathrm{km}$ per year; 1a, $2 \mathrm{a}$ - change in the pressing force after installation of PRP 3.2 pads 


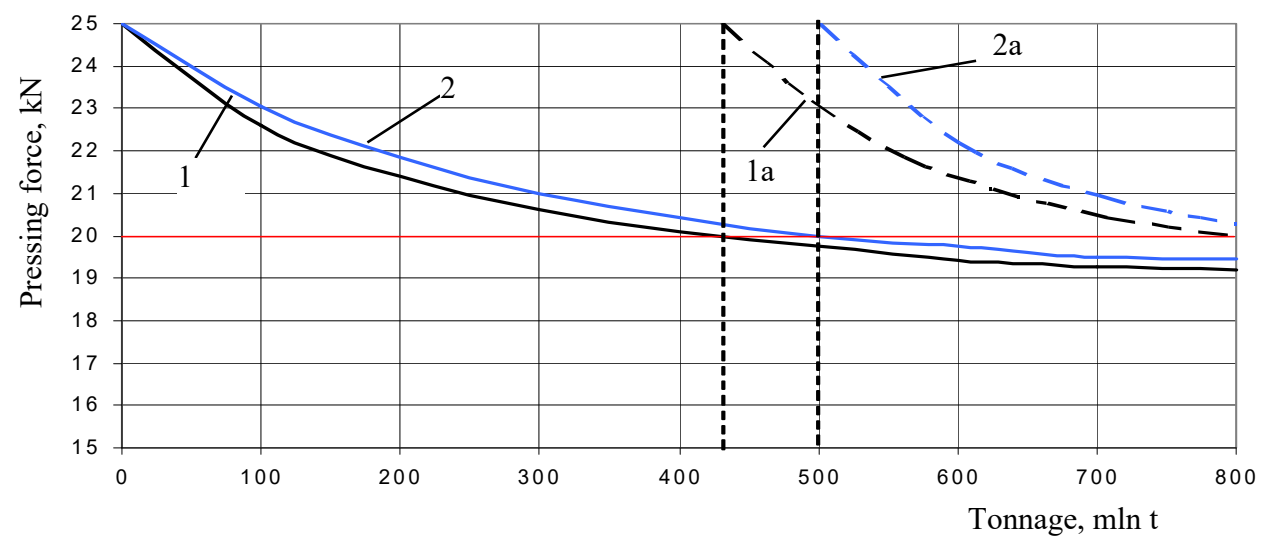

Fig. 5. Diagram of change in the pressing force between rail and tie in the assembly unit KPP-5: 1 - freight density $45 \mathrm{mln}$ tkm gross $/ \mathrm{km}$ per year; 2 - carrying capacity $60 \mathrm{mln}$ tkm gross $/ \mathrm{km}$ per year; $1 \mathrm{a}, 2 \mathrm{a}$ - change in the pressing force after installation of PRP 3.2.1 pads

Table 1. Reference periods for the pressing force to be restored in the assembly unit KPP-5 in dependence on the freight density

\begin{tabular}{|c|c|c|c|}
\hline \multirow{2}{*}{ № } & \multirow{2}{*}{$\begin{array}{c}\text { Freight density } \\
\text { mln tkm gross/km per year. }\end{array}$} & \multicolumn{2}{|c|}{$\begin{array}{c}\text { Reference periods for the pressing force in the } \\
\text { assembly unit to be restored }\end{array}$} \\
\cline { 3 - 4 } & 15 & $\mathrm{mln} \mathrm{t}$ & years \\
\hline 1 & 30 & 220 & 14.7 \\
\hline 2 & 45 & 350 & 12.7 \\
\hline 3 & 60 & 430 & 11.1 \\
\hline 4 & & 500 & 8.3 \\
\hline
\end{tabular}

Considering the fact that pads of $10 \mathrm{~mm}$ depth are more expensive, the final decision regarding the pad type should take into account the technical and economic assessment.

\section{Conclusions}

1. The formation of pressuring forces between rail and tie in the assembly unit KPP-5 is determined.

2. The dependencies of changes in residual deformations of terminals and pads, pad deterioration, changes in rigidity of PRP 2.1 pads in operation were obtained.

3. The periods when PRP 2.1 pads should be replaced for PRP 3.2 and PRP 3.2.1 pads under various operational conditions are determined. It will provide reliable work of KPP-5 fastenings during the whole overhaul period.

\section{References}

1. E.I. Danilenko, V.O. Yakovlyev, A.M. Orlovskyj, M.I. Karpov Instrukciya $z$ ulashtuvannya ta utrymannya koliyi zaliznyc Ukrayiny (Transport Ukrayiny, 2006).

2. E.I. Danylenko, V.V. Rybkin. Pravyla rozraxunkiv zaliznychnoyi koliyi na micznist $i$ stijkist (Transport Ukrayiny, 2006) .

3. V.G. Al'breht, E.M. Bromberg, N.B. Zverev, Besstykovoj put' (Moskow, Transport, 1982). 
4. E.M. Bromberg, M.F. Verigo, V.N. Danilov, Vzaimodejstvie puti I podviznogo sostava (Moskow, Transport, 1956).

5. G.M. Shahunjants, Zheleznodorozhnyj put', Monografija (Moskow, 1987).

6. M.F. Verigo, A.J. Kogan, Vzaimodejstvie puti $i$ podvizhnogo sostava (Moskow, Transport, 1986).

7. M.F. Verigo, Vestnik VNIIZhTa, 21 (5), 25-37 (2001).

8. V.I. Klimov, V.V. Rybkin, Trudy DIITa, 32(244), 72-84 (1987)

9. V.V. Govoruha. Mekhanika deformirovaniya i razrusheniya uprugih ehlementov promezhutochnyh relsovyh skreplenij (Dnepropetrovsk, 2005).

10. A. Darenskiy, D. Potapov, Y. Tuley, N. Bugaets, A. Malishevskaya, MATEC Web of Conferences. 116, 03001 (2017).

11. S. Panchenko, T. Butko, A. Prokhorchenko, L. Parkhomenko, O. Zhurba, International Journal of Engineering \& Technology. 7 (4.3), 217-221, (2018) 